\title{
Simulation of Ash Deposition Behavior in an Entrained Flow Coal Gasifier
}

\author{
Xijia Lu, Ting Wang \\ Energy Conversion \& Conservation Center, University of New Orleans, New Orleans, LA, USA \\ Email: xlv@uno.edu, twang@uno.edu
}

Received 16 April 2015; accepted 23 May 2015; published 28 May 2015

Copyright (C) 2015 by authors and Scientific Research Publishing Inc.

This work is licensed under the Creative Commons Attribution International License (CC BY). http://creativecommons.org/licenses/by/4.0/

\section{Abstract}

Fly ash deposition is an important phenomenon associated with ash/slag handling and discharge in the entrained-flow coal gasification process. Fouling and slagging inside the gasifier may cause reliability and safety problems because they can impose strong negative effects on the gasifier wall in the way of heat transfer and chemical corrosion. For these reasons, this study focuses on investigating the ash deposition distribution inside of a two-stage entrained-flow gasifier. The computational model is developed in order to simulate the gasification process with a focus on modeling ash formation, fly ash, and ash deposition. The Eulerian-Lagrangian approach is applied to solve the reactive thermal-flow field and particle trajectories with heterogeneous reactions. The governing equations include the Navier-Stokes equations, twelve species transport equations, and ten global chemical reactions consisting of three heterogeneous reactions and seven homogeneous reactions. The coal/ash particles are tracked with the Lagrangian method. The effects of different coal/ash injection schemes and different coal types on ash deposition have been investigated. The results show that the two-stage fuel feeding scheme could distribute the ash throughout a larger gasifier's volume and, hence, could reduce the peak ash deposition rate and make the ash distribution more uniform inside the gasifier. Gasification of a high-ash coal results in a high ash deposition rate, low syngas higher heating value (HHV), and low carbon conversion rate. The result of ash deposition rate in this study can be used as a boundary condition to provide ash particle influx distribution for use in slagging models.

\section{Keywords}

Fly Ash Deposition, Coal Gasification, Simulation of Multiphase Reactive Flows, Clean Coal Technology

\section{Introduction}

Gasification is an incomplete combustion process, converting a variety of carbon-based feedstock into clean 
synthetic gas (syngas), which is primarily a mixture of hydrogen $\left(\mathrm{H}_{2}\right)$ and carbon-monoxide (CO) as fuels. Feedstock is partially reacted with oxygen at high temperature and pressure, using less than $30 \%$ of the oxygen required for complete combustion (i.e., the stoichiometric ratio is 0.3 ). The syngas produced can be used as a fuel, usually for boilers or gas turbines to generate electricity. It can also be made into a substitute natural gas (SNG), hydrogen gas, and/or other chemical products. Gasification technology is applicable to any type of carbon-based feedstock, such as coal, heavy refinery residues, petroleum coke, biomass, and municipal wastes. To help understand the gasification process in gasifiers and subsequently use the learned knowledge to guide the design of more compact, more cost-effective, and higher performance gasifiers, computational fluid dynamics (CFD) has been widely employed as a useful tool to achieve these goals. As a part of this learning process, the CFD model is utilized to help provide some preliminary understanding of ash deposition behavior in an entrained flow gasifier.

Coal ash is the mineral residue that is obtained as a byproduct of the combustion and gasification of coal. When burned or gasified in industrial reactors, these mineral residuals are discharged from the flue gas or synthetic gas in the forms of fly ash, bottom ash, and slag. Fly ash, which constitutes $85 \%$ - $90 \%$ of the overall ash, is a fine, light gray powder made up of glassy spheres from less than 1 to more than 100 microns in size, (typically, 98\% smaller than 75 microns; 70\% - 80\% smaller than 45 microns). The material has a bulk density of about $0.8-1$ ton per cubic meter and a maximal density of $1000-1400 \mathrm{~kg} / \mathrm{m}^{3}$ [1]. Fly ash contains cenospheres-hollow spherical particles that have an especially low bulk density of $0.4-0.6$ tons per cubic meter and constitutes up to $5 \%$ of the ash weight. Cenospheres are suitable for certain special industrial applications. Bottom Ash, which constitutes about $10 \%$ - 15\% of the overall ash, has an appearance similar to dark-gray, coarse sand, and its particles are clusters of small granules, up to $10 \mathrm{~mm}$ in diameter (typically, 60\% - 70\% smaller than $2 \mathrm{~mm}$. 10\% - 20\% smaller than 75 microns). It has a bulk density of about 1 ton per cubic meter and a maximal density (modified) of $1200-1500 \mathrm{~kg} / \mathrm{m}^{3}$. Most entrained-flow coal gasifiers are designed to operate at temperatures above the ash fusion temperature, in which the ash melts and deposits along the wall, forming a slag layer. Up to $90 \%$ of the ash can be discharged as molten slag from the bottom of the furnace or gasifier to a waterquenched slag hopper, where it forms crystal pellets [2].

Slagging gasification has the advantages of higher energy efficiency, broader feedstock selection, as well as a higher utilization value of the low-carbon content slag residuals [3] [4]. However, the challenges of ash deposition and slag formation also need to be addressed carefully in the coal gasification process. The fouling and slagging may damage the gasifier refractory bricks and equipment, resulting in more frequent maintenance calls and increased maintenance cost. For instance, the accumulation and subsequent shedding of large ash deposits could restrict syngas flow, and the molten slag may cause excessive corrosion on the gasifier's refractory wall. Moreover, the slag may encounter a discharging problem when its viscosity becomes high due to gradual solidification [5]. Therefore, a good understanding of the ash deposition and slag formation behaviors is imperative to the gasifier's design and optimization as well as operation and maintenance.

Commonly, fouling is initiated by the deposition of ash within a thin layer of condensed vapor. The composition is mainly high in alkali metals [6]. The deposition behavior of particles can be explained by the surface deposition of sticky minerals and surface tension of the molten slag. For most cases, the innermost layers consist primarily of small particles, largely formed from sodium (Na), calcium (Ca), and magnesium (Mg), a portion of which can be transported to the surface by vapor phase diffusion and thermophoresis. The initial deposit layers can provide a sticky surface that traps incoming particles. Moreover, the initial layers could provide fluxing materials that will cause larger particles to melt. As a result of the insulating effect of the deposit layer on the surface, the outer layers are formed at higher temperature, which causes the ashes to melt, and slide down the surface as a molten slag layer. Once the liquid phase has formed at the outer layers, it becomes an efficient collector of ash particles, regardless of the individual melting characteristics of the particles [7].

Ash deposition mechanisms have been widely investigated in coal/biomass combustion reactors. Shao investigated the ash deposition that occurs during the co-firing of biomass/peat with coal in a pilot-scale fluidized-bed reactor [5]. His study discovered that the fluidized-bed combustion of an individual fuel or a fuel blended with another fuel of higher moisture content produced not only a more uniform temperature profile along the fluidized-bed column but also reduced the ash deposition rate. A higher chlorine concentration in the feed would generally result in a higher tendency of ash deposition. Adding sulfur into the fuel could effectively decrease the chloride deposition in the ash deposits via sulfation. The sulfur addition could also reduce the ash deposition rate for the combustion of lignite, while it slightly increased the ash deposition rate for the peat fuel.

Barroso et al. studied coal ash deposition in an entrained-flow reactor by using ASTM procedures and Com- 
puter-Controlled Scanning Electron Microscopy (SEM) [8]. The influence of coal type, blend composition, and operating conditions were investigated separately. A consistent relationship was found between the deposit growth rates and the aerodynamic diameter of the fly ash particles. Fernandez-Turiel, et al. experimentally studied the ash deposition in a pulverized coal-fired power plant after high-calcium lignite combustion [9]. They discovered that the formation of ash deposits was closely associated with gas-solid reactions. No liquid phases seemed to contribute to either the adhesion to walls or the joining of particles together. On the other hand, alkaline element compounds had no role in the buildup of deposits.

Regarding ash deposition in the coal gasification process, Xu et al. investigated the low temperature ash deposition behavior in a coal gasifier by using an experimental method. A laminar drop tube furnace was utilized in the experiment to simulate ash deposition behavior [7]. They found that the variations of flue gas temperature play an important role in the deposition of ash. Also, the ash deposition rate increases with bigger coal particle size, higher deposit surface temperature, and flue gas temperature. Cao, et al. investigated the characteristics and mechanism of fly ash deposited in the Shell coal gasification process [10]. The chemical composition, particle size distribution, surface topography, and elemental composition of fly ash samples derived from coal A and coal B were studied by an X-ray fluorescence spectrometer, a JX-2000 microscopic image analyzer, and a computer-controlled scanning electron microscope, respectively. The results showed that the ash deposition characteristics are determined by the surface properties and elemental composition of the fly ash particles in different coal types.

The CFD modeling of the ash deposition and slag formation mechanisms has been further developed in the recently years. Ahmadi, et al. developed a computational model for simulating the gas flow, thermal conditions, and ash transport and deposition patterns in the hot gas filtration systems [11]. The ash particle transport and deposition pattern was analyzed with the Largrangian particle tracking approach. Schulze developed a CFD based deposit formation model for biomass-fired boilers [12]. The model considered the condensation of ash vapors; deposition of coarse, salt-rich and silica-rich fly ash particles; brittle and ductile erosion of the deposit layer by non-sticky particles; aerosol formation; and ash deposition under the consideration of a single particle size class.

Yong et al. proposed a set of particle trap criteria for the slag-particle interaction and applied it in a 1-D slag flow model [13] [14]. Chen, et al. expanded Yong's slag model, along with sub-models designed to assess charslag interaction and wall burning, and implemented it in 3-D CFD simulations of oxy-coal combustion [2]. The slag deposition and thickness distribution along the circumference of the furnace wall due to a non-uniform flow field was presented. Most of the aforementioned studies are related to ash deposition in a combustion process where the gas and wall temperatures are higher than those in the gasifictin process. However, the CFD modeling of the ash deposition mechanism in an entrained flow coal gasification process has not been well developed. The purpose of this study is to incorporate the ash deposition mechanism into the complete coal gasification model. Each coal particle has been tracked by the Lagrangian method to go through the processes of coal surface moisture evaporation, devolatilization, coal combustion, coal gasification, and ash deposition. The ash deposition rates along the gasifier wall are investigated and compared among different cases by employing different coal feeding schemes and using different coal types. Moreover, the effect of the ash deposition rates on the gasification performance, including syngas temperature, composition, and higher heating value (HHV); carbon conversion rate are also investigated in this study.

\section{Global Gasification and Chemical Reactions}

This study deals with the global chemical reactions of coal gasification that can be generalized in reactions (R1) through (R11) in Table 1. In this study, the volatiles are modeled to go through a two-step thermal cracking process (R7-8) and the gasification processes (R9-10) with $\mathrm{CH}_{4}$ and $\mathrm{C}_{2} \mathrm{H}_{2}$ as the intermediate products. The empirical finite rate of the water gas shift reaction, $\mathrm{A}=2.75, \mathrm{E}=8.38 \times 10^{7} \mathrm{~kJ} / \mathrm{kmol}$, is adopted based on the investigation carried out by Lu and Wang [15] [16].

In order to investigate the effect of the ash content in the coal on the gasification performance, two types of coal with different ash contents are selected in this study. One is Illinois No. 6 coal (IL-6) with an ash content of 9.7\% by weight, whose composition is given in Table 2. The other coal is West Kentucky No. 11 (WK-11) with an ash content of $31.83 \%$ by weight, whose composition is given in Table 3 . The compositions of the volatiles are derived from each coal's heating value, proximate analysis, and ultimate analysis: 
Table 1. Summary of reaction rate constants used in this study.

\begin{tabular}{|c|c|c|c|c|c|c|}
\hline & \multirow{2}{*}{ Reactions } & \multirow{2}{*}{ Reaction Type } & \multirow{2}{*}{$\begin{array}{l}\text { Reaction } \\
\text { heat, } \Delta \mathrm{H}_{\mathrm{R}}^{\circ} \\
(\mathrm{MJ} / \mathrm{kmol})\end{array}$} & \multicolumn{2}{|c|}{$\begin{array}{c}\mathrm{k}=\mathrm{AT}^{\mathrm{n}} \exp (-\mathrm{E} / \mathrm{RT}) \\
(\mathrm{n}=0)\end{array}$} & \multirow{2}{*}{ Reference } \\
\hline & & & & A & $\mathrm{E}(\mathrm{J} / \mathrm{kmol})$ & \\
\hline \multicolumn{7}{|c|}{ Heterogeneous Reactions } \\
\hline R 1 & $\mathrm{C}(\mathrm{s})+1 / 2 \mathrm{O}_{2} \rightarrow \mathrm{CO}$ & Partial Combustion & -110.5 & 0.052 & $6.1 \times 10^{7}$ & [18] \\
\hline $\mathrm{R} 2$ & $\mathrm{C}(\mathrm{s})+\mathrm{CO}_{2} \rightarrow 2 \mathrm{CO}$ & $\begin{array}{l}\text { Gasification, } \\
\text { Boudouard Reaction }\end{array}$ & +172.0 & 0.0732 & $1.125 \times 10^{8}$ & [18] \\
\hline R 3 & $\mathrm{C}(\mathrm{s})+\mathrm{H}_{2} \mathrm{O} \rightarrow \mathrm{CO}+\mathrm{H}_{2}$ & Gasification & +131.4 & 0.0782 & $1.15 \times 10^{8}$ & [18] \\
\hline \multicolumn{7}{|c|}{ Homogeneous Reactions } \\
\hline R 4 & $\mathrm{CO}+1 / 2 \mathrm{O}_{2} \rightarrow \mathrm{CO}_{2}$ & Combustion & -283.1 & $2.2 \times 10^{12}$ & $1.67 \times 10^{8}$ & [19] \\
\hline R 5 & $\mathrm{CO}+\mathrm{H}_{2} \mathrm{O}(\mathrm{g}) \leftrightarrow \mathrm{CO}_{2}+\mathrm{H}_{2}$ & Water Gas Shift & -41.0 & $2.75 \times 10^{10}$ & $8.38 \times 10^{7}$ & {$[20]$} \\
\hline R 6 & $\mathrm{CO}+3 \mathrm{H}_{2} \leftrightarrow \mathrm{CH}_{4}+\mathrm{H}_{2} \mathrm{O}$ & Methanation & -205.7 & $\begin{array}{c}\mathrm{k}_{\mathrm{f}}=5.12 \times 10^{-14} \\
\mathrm{k}_{\mathrm{b}}=4.4 \times 10^{11}\end{array}$ & $\begin{array}{l}2.73 \times 10^{4} \\
1.68 \times 10^{8}\end{array}$ & [20] \\
\hline R 7 & $\begin{array}{c}\mathrm{CH}_{2.761} \mathrm{O}_{0.264} \mathrm{~N}_{0.055} \mathrm{~S}_{0.048} \mathrm{Cl}_{0.005} \rightarrow \\
0.256 \mathrm{CO}+0.466 \mathrm{H}_{2}+0.33 \\
\mathrm{CH}_{4}+0.2 \mathrm{C}_{2} \mathrm{H}_{2}+0.0275 \mathrm{~N}_{2}+ \\
0.005 \mathrm{HCl}+0.04 \mathrm{H}_{2} \mathrm{~S} \\
+0.008 \mathrm{COS}\end{array}$ & $\begin{array}{l}\text { Two-step Volatiles } \\
\text { Cracking for IL-6 Coal }\end{array}$ & +4.75 & \multicolumn{2}{|c|}{ Eddy dissipation } & \\
\hline R 8 & $\begin{array}{c}\mathrm{CH}_{3.187} \mathrm{O}_{0.336} \mathrm{~N}_{0.06} \mathrm{~S}_{0.01} \\
\rightarrow 0.8575 \mathrm{H}_{2}+0.334 \mathrm{CO}+0.264 \mathrm{CH}_{4} \\
+0.2 \mathrm{C}_{2} \mathrm{H}_{2}+0.03 \mathrm{~N}_{2}+0.008 \mathrm{H}_{2} \mathrm{~S}+ \\
0.002 \mathrm{COS}\end{array}$ & $\begin{array}{l}\text { Two-step Volatiles } \\
\text { Cracking for WK-11 } \\
\text { coal }\end{array}$ & +140 & \multirow{3}{*}{\multicolumn{2}{|c|}{ Eddy dissipation }} & \\
\hline R 9 & $\mathrm{CH}_{4}+1 / 2 \mathrm{O}_{2} \rightarrow \mathrm{CO}+2 \mathrm{H}_{2}$ & $\begin{array}{l}\text { Volatiles Gasification } \\
\text { via } \mathrm{CH}_{4}\end{array}$ & -35.71 & & & \\
\hline R10 & $\mathrm{C}_{2} \mathrm{H}_{2}+\mathrm{O}_{2} \rightarrow 2 \mathrm{CO}+\mathrm{H}_{2}$ & $\begin{array}{c}\text { Volatiles Gasification } \\
\text { via } \mathrm{C}_{2} \mathrm{H}_{2}\end{array}$ & -447.83 & & & \\
\hline R11 & $\mathrm{H}_{2}+1 / 2 \mathrm{O}_{2} \rightarrow \mathrm{H}_{2} \mathrm{O}$ & Oxidation & -242 & $6.8 \times 10^{15}$ & $1.68 \times 10^{8}$ & {$[20]$} \\
\hline
\end{tabular}

Table 2. The proximate and ultimate analyses of Illinois No.6 (IL-6) coal.

\begin{tabular}{|c|c|}
\hline Coal & IL-6 \\
\hline \multicolumn{2}{|c|}{ Proximate Analysis (wt \%) } \\
\hline Moisture & 11.12 \\
\hline VM & 34.99 \\
\hline Ash & 9.7 \\
\hline Fixed Carbon & 44.19 \\
\hline Heating Value (HHV) & 27.1(MJ/kg) \\
\hline \multicolumn{2}{|c|}{ Ultimate Analysis (wt \%) } \\
\hline Moisture & 11.12 \\
\hline Ash & 9.7 \\
\hline $\mathrm{C}$ & 63.75 \\
\hline $\mathrm{H}$ & 4.5 \\
\hline $\mathrm{N}$ & 1.25 \\
\hline $\mathrm{S}$ & 2.51 \\
\hline $\mathrm{O}$ & 6.88 \\
\hline $\mathrm{Cl}$ & 0.29 \\
\hline
\end{tabular}


Table 3. The proximate and ultimate analyses of West Kentucky No. 11 (WK-11) coal.

\begin{tabular}{cc}
\hline Coal & WK-11 \\
\hline & \\
Moisture & Proximate Analysis (wt \%) \\
VM & 10.28 \\
Ash & 26.11 \\
Fixed Carbon & 31.78 \\
Heating value (HHV) & 31.83 \\
\hline
\end{tabular}

\begin{tabular}{cc}
\hline & Ultimate Analysis (wt \%) \\
\hline Moisture & \\
Ash & 10.28 \\
C & 31.78 \\
H & 44.56 \\
N & 3.382 \\
S & 0.8972 \\
O & 3.391 \\
\hline
\end{tabular}

$\mathrm{CH}_{2.761} \mathrm{O}_{0.264} \mathrm{~N}_{0.055} \mathrm{~S}_{0.048} \mathrm{Cl}_{0.005}$ for IL-6 and $\mathrm{CH}_{3.187} \mathrm{O}_{0.336} \mathrm{~N}_{0.06} \mathrm{~S}_{0.01}$ for WK-11. The oxidant is considered to be a continuous flow, and the coal particles are considered to be the discrete phase. The coal particles include the fixed carbon, volatiles, inherent moisture, and ash. The water content is treated with two separated components: the inherent moisture inside the coal and the moisture on the coal surface. In order to include the energy to overcome the resistance of driving the inherent moisture out of the pores of the coals, a simple model is applied by increasing the standard latent heat of $\mathrm{H}_{2} \mathrm{O}$ by $20 \%$. For surface water over the particle, the standard latent heat is used. The volatiles are modeled such that they are thermally cracked to $\mathrm{CO}, \mathrm{H}_{2}, \mathrm{CH}_{4}, \mathrm{C}_{2} \mathrm{H}_{2}, \mathrm{~N}_{2}, \mathrm{HCl}, \mathrm{H}_{2} \mathrm{~S}$, and COS. Based on DOE/NETL's report [17], the ratio of $\mathrm{H}_{2} \mathrm{~S} / \mathrm{COS}$ is given to be 5:1. All these cracked volatile products are considered to be part of the continuous gas phase.

\section{Computational Model}

The computational model and submodels (devolatilization, reactions, particle dynamics, gasification) used in the study are the same as initially developed by Silaen and Wang [22] and improved by Lu and Wang [23] [24]. Therefore, the governing and associated equations and detailed modeling intricacies are not repeated here, but they are briefly summarized below. The time-averaged, steady-state Navier-Stokes equations as well as the mass and energy conservation equations are solved. Species transport equations are solved for all gas species involved. The standard k- $\varepsilon$ turbulence model with standard wall function is used to provide closure. The P1 model is used as the radiation model. The Chemical Percolation Devolatilization (CPD) model is used as the devolatilization model. The flow (continuous phase) is solved in Eulerian form as a continuum while the particles (dispersed phase) are solved in Lagrangian form as a discrete phase. A stochastic tracking scheme is employed to model the effects of turbulence on the particles. The continuous phase and discrete phase are communicated through drag forces, lift forces, heat transfer, mass transfer, and species transfer.

\subsection{Discrete Phase Modeling}

Gasification or combustion of coal particles undergoes the following global processes: 1) inert heating; 2) evaporation of surface moisture; 3) devolatilization and demoisturization; 4) coal combustion and gasification; and 5) ash deposition. The initially inert coal particles will go through a heating process to increase the particle temperature. When the surface temperature of a coal particle reaches the vaporization temperature, $T_{\text {vap }}$, the surface moisture starts to evaporate. The vaporization temperature is determined by the water vapor partial pressure. Water evaporation continues until the droplet reaches the boiling point, $\mathrm{T}_{\mathrm{bp}}$, when the inherent moisture starts to evaporate and gets driven out. The boiling temperature is determined by the pressure inside the gasifier, i.e., the total pressure of all the gases. In the meantime, devolatilization takes place when the temperature of the coal particle reaches the vaporization temperature of the volatiles, and remains in effect until the volatiles are completely vaporized out of the coal particles. Here, the vaporization temperature refers to combusting materials 
(volatiles), and is different from the vaporization temperature of surface moisture. Silaen and Wang [22] compared the effect of four different devolatilization models on the gasification process. They concluded that the rate calculated by the Kobayashi two-competing rates devolatilization model is very slow, while that of the Chemical Percolation Devolatilization (CPD) model gives a more reasonable result. Therefore, the CPD model was chosen for this study. The CPD model considers the chemical transformation of the coal structure during devolatilization. It models the coal structure transformation as a transformation of a chemical bridge network, which results in the release of light gases, char, and tar. The initial fraction of the bridges in the coal lattice is 1 , and the initial fraction of char is 0 . The lattice coordination number is 5 . The cluster molecular weight is 400 , and the side chain molecular weight is 50 .

\subsection{Particle Reactions}

The reactions of the particles occur after the devolatilization process has finished. The rate of depletion of solid due to a surface reaction is expressed as:

$$
\begin{gathered}
\bar{R}=A \eta Y R \\
R=k\left(p_{n}-\frac{R}{D}\right)^{N}
\end{gathered}
$$

where

$\bar{R}=$ rate of particle surface species depletion $(\mathrm{kg} / \mathrm{s})$

$A=$ particle surface area $\left(\mathrm{m}^{2}\right)$

$Y=$ mass fraction of the solid species on the surface of the particle

$\eta=$ effectiveness factor (dimensionless)

$R=$ rate of particle surface species reaction per unit area $\left(\mathrm{kg} / \mathrm{m}^{2} \cdot \mathrm{s}\right)$

$p_{n}=$ bulk concentration of the gas phase species $\left(\mathrm{kg} / \mathrm{m}^{3}\right)$

$D=$ diffusion rate coefficient for reaction

$k=$ kinetic reaction rate constant (units vary)

$N=$ apparent order of reaction.

The kinetic reaction rate constant is usually defined in an Arrhenius form as

$$
k=A T^{n} \mathrm{e}^{-(E / R T)} .
$$

For reaction order $N=1$, the rate of particle surface species depletion is given by

$$
\bar{R}=A \eta Y p_{n} \frac{k D}{D+k} .
$$

For reaction order $N=0$,

$$
\bar{R}=A \eta Y k .
$$

The unit of the rate of depletion of the solid $\bar{R}$ is $\mathrm{kg} / \mathrm{s}$. The kinetic reaction rate constant $k\left(\mathrm{~kg} / \mathrm{m}^{2} \cdot \mathrm{s}\right)$ for the solid-gas char reactions are determined by the kinetic reaction rate constants adopted from published literatures as presented in Table 1 .

\subsection{Coal Particle Motion Theory}

In this study, coal particles are treated as a discrete phase, so the Lagrangian method is adopted to track each particle. The discrete phase is justified in entrained-flow gasification process because the average particle concentration is lower than $10 \%$. Particles in the airflow can encounter inertia and hydrodynamic drag. Because of the forces experienced by the particles in a flow field, the particles can be either accelerated or decelerated. The velocity change is determined by the force balance on the particle, which can be formulated by:

$$
\frac{\mathrm{d} u_{p}}{\mathrm{~d} t}=F_{D}+F_{g}+F_{x}
$$

where $F_{D}$ is the drag force per unit particle mass and: 


$$
F_{D}=\frac{18 \mu}{\rho_{p} d_{p}^{2}} \frac{C_{D} \operatorname{Re}}{24}\left(v-v_{p}\right) m_{p}
$$

where $m_{p}$ is the particle mass, $d_{p}$ is the particle diameter, $v$ is the fluid phase velocity, $v_{p}$ is the particle velocity, $\rho$ is the fluid phase density, $\rho_{p}$ is the particle density, $g$ is gravity, $\mu$ is the fluid phase molecular viscosity, and $C_{D}$ is the drag coefficient. The gravitational force, $F_{g}$, is calculated as the second term in Equation (6) as:

$$
F_{g}=\frac{g\left(\rho_{p}-\rho\right)}{\rho_{p}} m_{p}
$$

The relative Reynolds number, Re, is defined as:

$$
\operatorname{Re}=\frac{\rho d_{p}\left|v_{p}-v\right|}{\mu}
$$

$F_{x}$ in Equation (6) is an additional acceleration (force/unit particle mass) term, and typically includes the “virtual mass” force, thermophoretic force, Brownian force, Saffman’s lift force, etc. In this study, the thermophoretic and Saffman's list forces are included.

\subsubsection{Virtual Mass Force}

The "virtual mass" force is the force required to accelerate the fluid surrounding the particle. This force can be written as:

$$
F_{x}=\frac{1}{2} \frac{\rho}{\rho_{p}} \frac{\mathrm{d}}{\mathrm{d} t}\left(u-u_{p}\right)
$$

This force is important only when $\rho>\rho_{p}$. It is not included in this study since the density of each coal particle is much larger than the density of the surrounding gas mixture.

\subsubsection{Brownian Force}

The Brownian force is caused by the random impacts of the particles with agitated gas molecules. For submicron-sized particles, the Brownian force could be quite important. In particular, near solid surfaces where the intensity of turbulence becomes negligibly small, the Brownian force could be an important transport mechanism. In this study, the size of each coal particle is $50 \mu \mathrm{m}$, so the Brownian force is not included.

\subsubsection{Saffman's Lift Force}

The Saffman's lift force, or lift due to shear, is based on the derivation from Li and Ahmadi [25], which is expressed in a generalized form originating from Saffman [26]:

$$
\boldsymbol{F}=\frac{2 K v^{1 / 2} \rho d_{i j}}{\rho_{p} d_{p}\left(d_{l k} d_{k l}\right)^{1 / 4}}\left(\boldsymbol{v}-\boldsymbol{v}_{p}\right)
$$

where $K=2.594$ and $d_{i j}$ is the deformation tensor. This form of the lift force is intended for small particle Reynolds numbers. Also, the particle Reynolds number based on the particle-fluid velocity difference (slip velocity) must be smaller than the square root of the particle. The Reynolds number is based on the shear field. In this study, Saffman's lift force reaches about $30 \%$ of $F_{g}$, so it is included in the particle motion model.

\subsubsection{Magnus Force}

The Magnus force is the lift force acting on a particle that develops due to its rotation. The lift is caused by the pressure difference between both sides of the particle, resulting from the velocity difference between the same due to rotation. Kallio and Reeks [27] noted that, in most regions of the flow field, the Magnus force is not important and at least an order of magnitude smaller than the Saffman force. As a consequence, it is ignored in this study.

\subsubsection{Thermophoretic Force}

When a particle exists in a flow field with temperature gradients, the force that arises on the particle due to this 
temperature gradient is called the thermophoretic force. This force is caused by the unequal momentum between the particle and the fluid. The higher molecular velocities on one side of the particle due to the higher temperature give rise to more momentum exchange and a resulting force in the direction of decreasing temperature. An extensive review of thermophoresis by Talbot et al. indicated that the following equation for the thermophoretic force, $F_{X}$, provides the best fit with experimental data over a wide range of Knudsen numbers [28]:

$$
F_{x}=-\frac{6 \pi d_{p} \mu^{2} C_{s}\left(K+C_{t} K n\right)}{\rho\left(1+3 C_{m} K n\right)\left(1+2 K+2 C_{t} K n\right)} \frac{1}{m_{p} T} \frac{\partial T}{\partial x}
$$

where

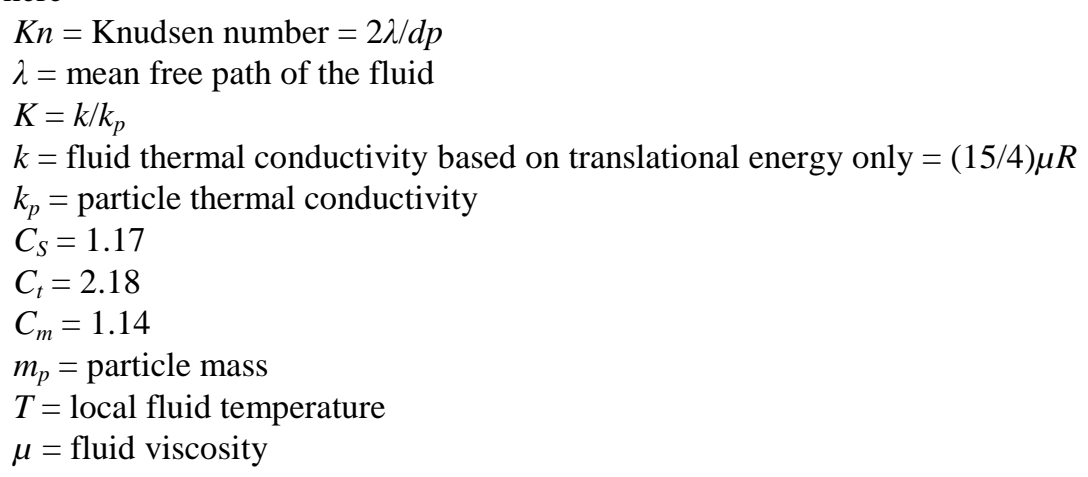

This expression assumes that the particle is a sphere and that the fluid is an ideal gas. In this study, the local temperature gradient in the flow field is important because of local combustion and gasification reactions between the coal particles and gas mixture. Therefore, the thermophoretic force is considered in this study.

\subsection{Turbulent Dispersion of Particles}

The dispersion of particles due to turbulence in the fluid phase is predicted by using a stochastic tracking scheme, which is modeled with the eddy lifetime. In this model, each eddy is characterized by the Gaussian-distributed, random velocity fluctuations $u^{\prime}, v^{\prime}, w^{\prime}$, and a time scale $\tau_{e}$. Therefore, the particle trajectories are calculated by using the instantaneous flow velocity (u) rather than the average velocity $(\bar{u})$. The velocity fluctuation is then given as:

$$
u=\bar{u}+u^{\prime}, \quad u^{\prime}=\zeta\left(\overline{u^{\prime 2}}\right)^{0.5}=\zeta(2 k / 3)^{0.5}
$$

where $\zeta$ is a normally distributed random number. This velocity will apply during a characteristic lifetime of the eddy $\left(t_{e}\right)$, calculated from the turbulence kinetic energy and dissipation rate. After this time period, the instantaneous velocity will be updated with a new $\zeta$ value until a full trajectory is obtained.

\subsection{Computational Models and Assumptions}

The computational domain and elements on the gasifier wall are shown in Figure 1 . The grid consists of 1,106,588 unstructured tetrahedral cells. In the simulation, the buoyancy force is considered, varying fluid properties are calculated for each species and the gas mixture, and the walls are assumed impermeable and adiabatic. Since each species' properties, such as density, $\mathrm{C}_{\mathrm{p}}$-value, thermal conductivity, absorption coefficient, etc. are all functions of temperature and pressure, their local values are calculated by using a piecewise polynomial approximation method. The mixture properties are calculated by taking the mass-weighted average. The flow is steady and the no-slip condition (zero velocity) is imposed on the wall surfaces.

\subsection{Boundary and Inlet Conditions}

The coal is fed as dry powder containing only the inherent moisture. The total mass flow rates of the IL-6 bituminous coal and the oxidant are $11.4 \mathrm{~kg} / \mathrm{s}$ and $7.64 \mathrm{~kg} / \mathrm{s}$, respectively. The total mass flow rate of WK-11 coal and the oxidant are $11.4 \mathrm{~kg} / \mathrm{s}$ and $5.36 \mathrm{~kg} / \mathrm{s}$, respectively. The gasifier's capacity is around 1000 tons of coal per day, and the energy output rate is around $110 \mathrm{MW}$. These oxidant/coal feed rates both give the same $\mathrm{O}_{2} / \mathrm{C}$ stoi- 


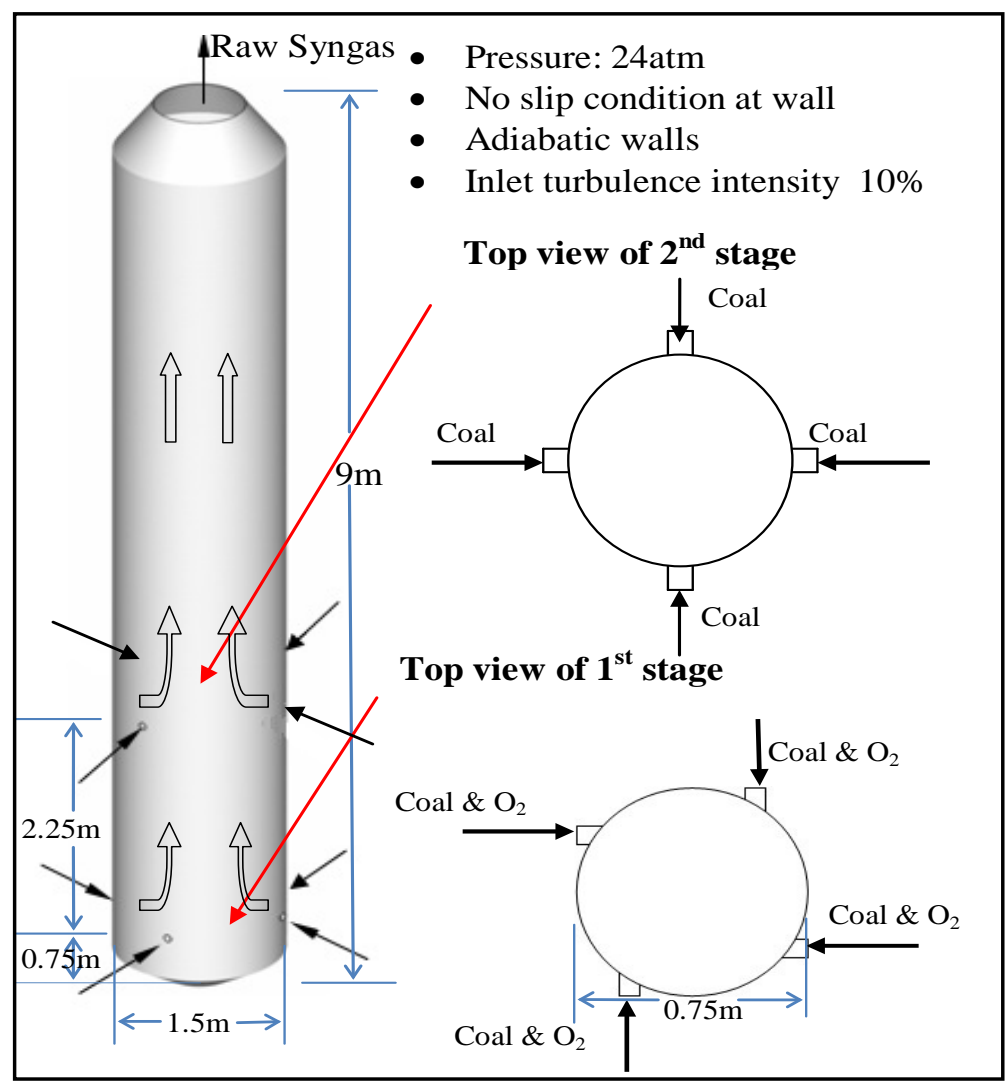

Figure 1. Schematic of the two-stage entrained-flow gasifier.

chiometric ratio of 0.3 , which is defined as the percentage of oxidant provided over the stoichiometric amount required for complete combustion of carbon. For the dry coal feed condition, $\mathrm{N}_{2}$ ( $5 \%$ of the total weight of the oxidant) has been injected to transport the coal powder into the gasifier. Both inherent moisture and ash are treated as part of the coal particles in the discrete phase model, while $\mathrm{N}$ is treated as $\mathrm{N}_{2}, \mathrm{Cl}$ as $\mathrm{HCl}$, and $\mathrm{S}$ as $\mathrm{H}_{2} \mathrm{~S} / \mathrm{COS}$ through the volatile cracking model. All of these cracked volatile products are considered to be a continuous gas phase. The inherent moisture is modeled to be released during the early demoisturization process. The vaporized water vapor is modeled as saturated water vapor with $100 \%$ concentration at the coal surface, which is diffused and convected away from the coal surface via the water specie transported equation. When all the inherent moisture is vaporized, the coal particle goes through the heterogeneous dry coal gasification process.

The oxidant is considered to be a continuous flow, and the coal is considered to be a discrete flow. The discrete phase includes inherent moisture, volatile matters, fixed carbon, and ash. The walls are all set to be adiabatic and are imposed with the no-slip condition (i.e., zero velocity). The operating pressure inside the gasifier is set at $24 \mathrm{~atm}$. The outlet is set at a constant pressure of $24 \mathrm{~atm}$. The syngas is considered to be a continuous flow, and the coal particles from the injection locations are considered to be discrete particles. The particles are considered to be perfectly spherical droplets of uniform size with a diameter of $50 \mu \mathrm{m}$ each. Although the actual size distribution of the coal particles is non-uniform, a simulation using a uniform particle size distribution provides a more convenient way to track the reaction process of coal particles than a non-uniform size distribution.

\subsubsection{Ash Deposition Model}

The discrete phase motion is represented by a sufficient number of representative coal particles. The trajectory of each coal particle is calculated by a stochastic tracking method. Each coal particle will go through all the processes stated above: surface moisture evaporation, devolatilization, coal oxidation, and gasification. The unburned char and ash will either be entrained to the exit of the gasifier by the syngas, or get stuck on the wall and form slag. Slag will be formed when the operating temperature of the gasifier is above the ash fusion tempera- 
ture.

The boundary condition of the discrete phase at the walls is assigned as "trap," which means that the unburned char and ash particles will stick on the wall when they reach the wall boundary. This model is proposed for ash deposition based on the assumption that the wall is hotter than the ash fusion temperature and the slagging wall is extreme sticky, so it traps all of the incoming particles once they touch the wall. Once the ash particle is trapped, it is assumed that it will move slowly with the molten slag and no further reaction will continue in the calculation domain. The ash melting process starts from the initial ash deformation temperature to the final stage of fluid temperature, which range from $844 \mathrm{~K}$ to $1014 \mathrm{~K}\left(1060^{\circ} \mathrm{F}-1366^{\circ} \mathrm{F}\right)$ for IL-6 coal and from $853 \mathrm{~K}$ to $1014 \mathrm{~K}\left(1076^{\circ} \mathrm{F}-1341^{\circ} \mathrm{F}\right)$ for WK-11 coal [29]. The ash fusion temperature usually refers to the initial ash deformation temperature, when the ash becomes sticky. The preliminary CFD result showed that almost all the gasifier's wall temperature is indeed higher than the fusion temperatures of both coals.

The ash deposition rate in this study is defined as:

$$
R_{\text {deposition }}=\sum_{P=1}^{N_{\text {particles }}} \frac{\dot{m}_{p}}{A_{\text {face }}}
$$

$N_{\text {particle }}$ is the total number of particles stick on the wall cells, which is tracked by Lagrangian method, $m_{p}$ is the mass of each particle, $A_{\text {face }}$ is the area of the cell face at the wall. In this study, only the ash deposition rate is considered for the ash deposition mechanism. The more complex particle-wall interaction models and slag forming mechanism are not included in the current study. More complex models usually involve the establishment of the criteria for the ash "trap" and "rebound" conditions, which are related to the characteristics of the particles' incoming velocities, diameters, and approaching angles, the slag surface tension (associated with Weber number), and the local wall temperature.

\subsubsection{Computational Methodology}

The computation is performed using the finite-volume-based commercial CFD software, FLUENT 14.0, from ANSYS, Inc. The simulation is steady-state and uses the pressure-based solver, which employs an implicit pressure-correction scheme and decouples the momentum and energy equations. The SIMPLE algorithm is used to couple the pressure and velocity. The second-order upwind scheme is selected for spatial discretization of the convective terms. For the gas/particle phase coupling, where the Eulerian-Lagrangian approach is used, the iterations are conducted by alternating between the continuous and the discrete phases. Initially, one iteration in the continuous phase is conducted followed by one iteration in the discrete phase to avoid having the flame die out. The iteration number in the continuous phase gradually increases as the flame becomes more stable. Once the flame is stably established, fifteen iterations are performed in the continuous phase followed by one iteration in the discrete phase. The drag, particle surface reactions, and mass transfer between the discrete and the continuous phases are calculated. Based on the discrete phase calculation results, the continuous phase is updated in the next iteration, and the process is repeated.

Converged results are obtained when the residuals satisfy a mass residual of $10^{-3}$, an energy residual of $10^{-5}$, and momentum and turbulence kinetic energy residuals of $10^{-4}$. These residuals are the summation of the imbalance in each cell.

\section{Results and Discussions}

The effects of different coal/ash injection schemes (single-stage versus two-stage injection) and different coal types (low-ash versus high-ash coal) on ash deposition are investigated. For the two-stage injection, only coal is distributed in two stages, $100 \%$ of the oxygen is still injected in the first stage. The following four cases are studied. In the baseline (Case 1), a dry-fed, two-stage configuration is used with a fuel distribution of $100 \%$ - $0 \%$ between the first and the second stages.

- Case 1: IL-6 coal, $100 \%$ - $0 \%$ distribution, injection only in the first stage

- Case 2: IL-6 coal, 50\% - 50\% equal injection distribution in 2 stages

- Case 3: IL-6 coal, 25\% - 75\% injection distribution in 2 stages

- Case 4: WK-11 coal, 50\% - 50\% equal injection distribution in 2 stages

\subsection{Effect of Different Coal Injection Schemes on Ash Deposition Rate}

One of the purposes of employing a two-stage coal injection scheme is to keep the gasifier temperature low 
downstream from the $2^{\text {nd }}$ stage, and, thus, extend the life of the refractory bricks, decrease the gasifier shut-down frequency for maintenance, and reduce maintenance costs. By only injecting a certain amount of dry coal without oxygen in the second gasifier stage, only endothermic gasification reactions will occur, thus lowering the exit temperature of the syngas compared to a one-stage injection scheme. Table 4 shows the results of syngas composition, temperature, and higher heating value (HHV) at the exit of the gasifier for Cases 1,2 , and 3 . The more coal is injected into the second stage of the gasifier, the lower the syngas temperature is at the exit of the gasifier. The exit syngas temperature decreases from $2079 \mathrm{~K}$ (Case 1) to $1902 \mathrm{~K}$ (Case 2), and further to 1,819 K (Case 3). The results show that the carbon conversion rates are the same for each coal feeding scheme: all three cases reach 98\% carbon conversion, but the syngas higher heating value (HHV) increases from 205,896 kJ/kmol to $208,726 \mathrm{~kJ} / \mathrm{kmol}$ when the coal (no oxygen) feeding at the second stage increases from $0 \%$ to $75 \%$.

Figure 2 shows the selected coal particle traces inside of the gasifier. The tangential fuel injectors at the first stage make the coal particles spiral upward, providing more surface interaction between the solid particles and the continuous flow. Most of the coal particles move closer to the wall rather than occupy the central part of the gasifier due to the centrifugal force generated by the spiraling motion. In addition to the pathlines plots shown in Figure 2, this phenomenon can be also evidenced in the coal particle concentration plots shown in Figure 3 for all three cases with or without second-stage injections. In Case 1, 100\% of the coal particles are injected at the first stage, resulting in the highest particle concentration appearing in the lower part of the gasifier, close to the second fuel injection area. In Case 2, 50\% of the coal particles are injected at the second stage, resulting in more uniformly distributed particle concentration along the gasifier compared to Case 1, although the highest particle concentration still appears in the lower part of gasifier. In Case 3, heavy loads of particle concentration start to

Table 4. The syngas composition, temperature and higher heating value (HHV) at the exit of gasifier for Cases 1,2 , and 3.

\begin{tabular}{|c|c|c|c|}
\hline Syngas (vol\%) & Case $1100 \%$ - 0\% & Case $250 \%$ - 50\% & Case 3 25\% - 75\% \\
\hline $\mathrm{CO}$ & 0.39 & 0.39 & 0.40 \\
\hline $\mathrm{CO}_{2}$ & 0.11 & 0.11 & 0.10 \\
\hline $\mathrm{H}_{2}$ & 0.32 & 0.32 & 0.32 \\
\hline $\mathrm{H}_{2} \mathrm{O}$ & 0.10 & 0.11 & 0.10 \\
\hline Other Species & 0.08 & 0.07 & 0.08 \\
\hline $\mathrm{T}(\mathrm{K})$ & 2079 & 1902 & 1819 \\
\hline HHV (kJ/kmol) & 205,896 & 206,303 & 208,726 \\
\hline Carbon Conversion Rate & $98 \%$ & $98 \%$ & $98 \%$ \\
\hline
\end{tabular}
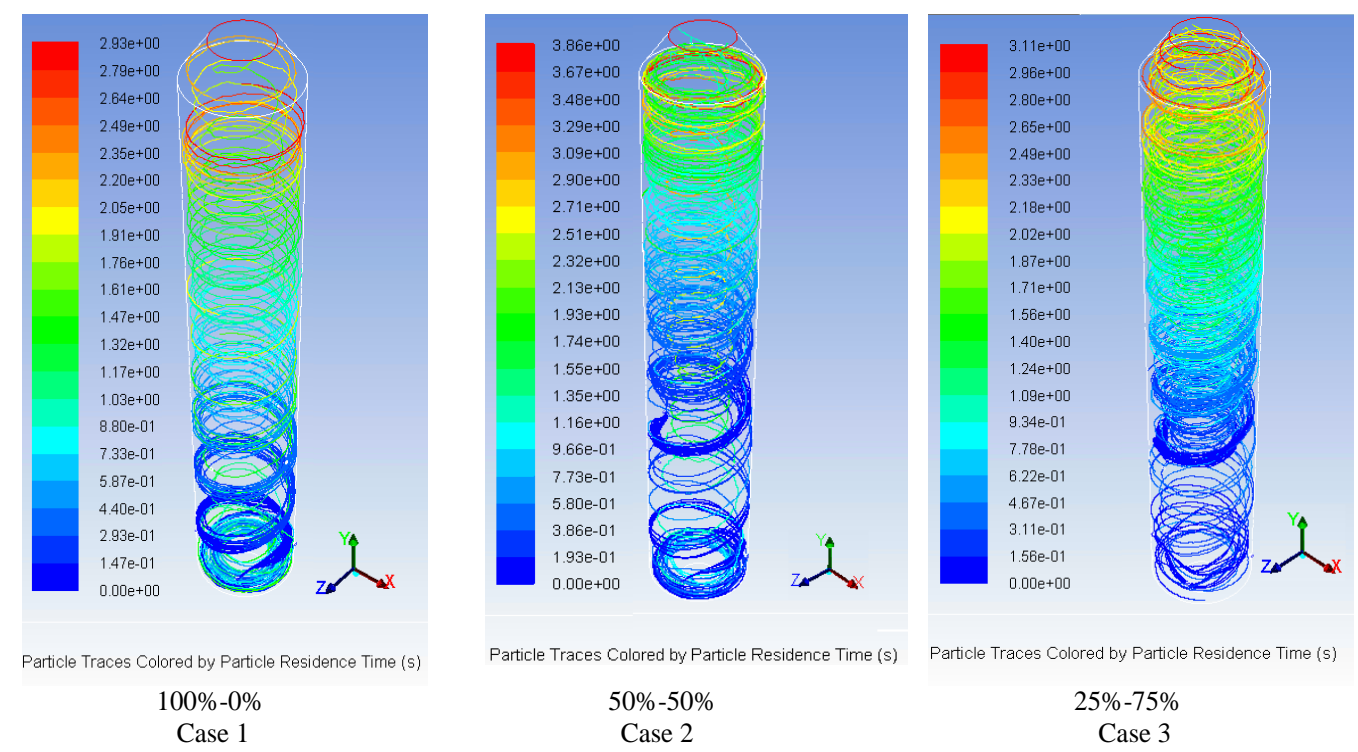

Figure 2. Coal particle traces for Cases 1, 2, and 3. 


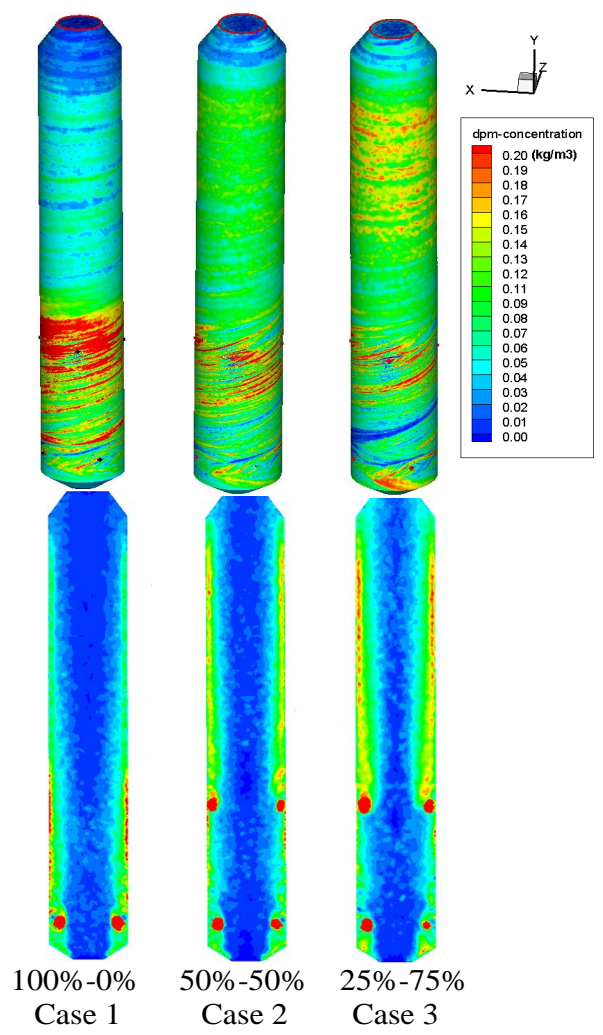

Figure 3. Contour of the coal particle concentration $\left(\mathrm{kg} / \mathrm{m}^{3}\right)$ for Cases 1,2 , and 3 . The upper figure shows the coal particle concentration on the wall while the lower figure shows the coal particle concentration on the central plane.

show up in the upper part of gasifier, since $75 \%$ of the coal particles are injected at the second stage. All of the characteristics of coal particle movement are shown as pathlines in Figure 2, and the distribution of particle concentration inside the gasifier is shown in Figure 3. Both of these factors directly affect the ash deposition phenomenon.

Figure 4 shows the contour of and area-averaged ash deposition rates along the gasifier height for the first three cases. In Case 1, the ash deposition rate in the upper part of the gasifier is much higher than it is in the bottom of gasifier. The highest ash deposition rate is around $0.051 \mathrm{~kg} / \mathrm{m}^{2}-\mathrm{s}$, appearing at the height of $4 \mathrm{~m}$, which is roughly $1 \mathrm{~m}$ higher than the second fuel injection location. In Case 2, as $50 \%$ of the coal is injected at the second stage, the ash deposition rate in the upper part of the gasifier decreases from Case 1, and the peak ash deposition rate appears at the same location as Case 1, but the value is reduced to $0.032 \mathrm{~kg} / \mathrm{m}^{2}$-s, which is $63 \%$ of the value seen in Case 1. In Case 3, since 75\% of the coal is injected at the second stage, the peak ash deposition rate shifts to the upper part of gasifier, at the height of $7.5 \mathrm{~m}$. The peak value is about $0.027 \mathrm{~kg} / \mathrm{m}^{2}$-s, which is about $53 \%$ of the peak deposition rate in Case 1 .

Compared to the one-stage fuel injection scheme, the two-stage fuel injection scheme could distribute ash deposition into a larger gasifier's area and, hence, reduce peak ash deposition locally. A more uniform ash distribution can hypothetically form a more uniformly-distributed, solidified slag layer to protect the wall refractory. However, when the slag layer grows thicker, the outer layer will start to flow down as molten slag. Another slagging model will be needed to simulate the ash melting and molten ash solidification and flowing phenomena. The ash deposition rate predicted by this study can serve as a useful boundary condition for slagging models.

\subsection{Effect of Different Types of Coal on Ash Deposition Rate}

In order to investigate the effects of using coals with different ash contents on the ash deposition rate in the gasifier, West Kentucky No. 11 (WK-11) coal has been used as a representative of coals with high ash content. In this case, the ash content is $31.78 \%$ by weight. The detailed WK-11 coal information is shown in Table 3 . The 


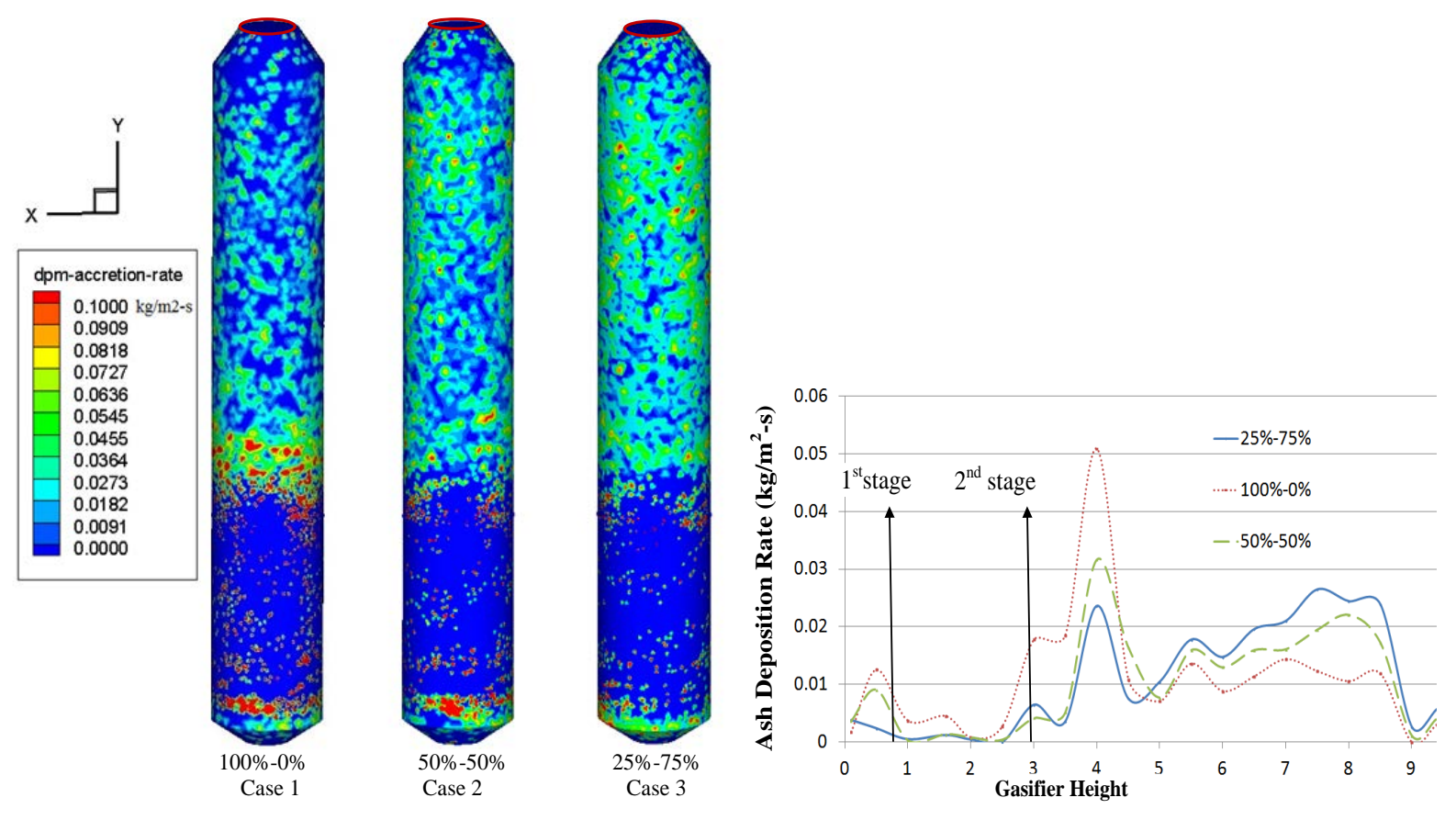

Figure 4. Contour of and area-weighted average ash deposition rates along the gasifier for Cases 1 - 3.

$50 \%$ - 50\%, two-stage coal feeding scheme is employed as Case 4, and the result is compared with the previously described Case 2. Table 5 shows the comparison of syngas composition, temperature, and $\mathrm{HHV}$ at the exit between Cases 2 and 4. It can be seen that WK-11 coal has a poor gasification performance because of the low carbon conversion rate, 52\%. WK-11 coal has $31.78 \%$ ash content, which is about two times more than the ash content in IL-6 coal. This non-reactive, high ash content seems to inhibit the effective reaction of carbon in the coal particles. Thus, most of the particles that hit the wall, and are subsequently trapped by it, contain unburned char. The low carbon conversion rate leads to a lower syngas HHV. Based on the total syngas HHV rate at the exit of the gasifier, the value in Case 4 (WK-1 coal) is $114,432 \mathrm{~kW}$, only $61 \%$ of the value $188,706 \mathrm{~kW}$ in Case 2 (IL-6 coal).

Figure 5 shows the coal particle concentrations for Cases 2 and 4, and Figure 6 shows the area-weighted average of the ash deposition rates along the gasifier walls for Cases 2 and 4 . Both figures indicate that the peak ash deposition rates of both cases appear at the same location: at the height of $4 \mathrm{~m}$. However, the peak ash deposition rate for Case 4 is around $0.35 \mathrm{~kg} / \mathrm{m}^{2}$-s, which is about 11 times the value found in Case 2 . Table 5 shows both the char and ash deposition rates for Cases 2 and 4 . The large difference of the ash deposition rates between Case 4 and Case 2 is caused by two reasons. First, the ash content of WK-11 coal is 3.3 times that of IL-6. The total ash deposition rate at the wall in Case 4 is $3.619 \mathrm{~kg} / \mathrm{s}$, which is 3.9 times that of Case $2(0.922 \mathrm{~kg} / \mathrm{s})$. Second, a large portion of the coal of the coal particles are trapped by the wall before they can completely react with the oxygen and syngas.

The current model assumes that no reaction occurs once the char is trapped on the wall. Under this assumption, the total un-reacted char deposition on the wall in Case 4 is $1.752 \mathrm{~kg} / \mathrm{s}$ (about $34.5 \%$ of the total char in the WK-11 coal), which is 19 times that of Case 2. If using WK-11 coal for gasification, the large amount of unreacted char is deposited on the wall together with the ash, and the carbon conversion rate is very low, only $52 \%$. Based on the current model with no char being able to continuously react in the wall layer, almost little char can escape to the exit of the gasifier $(0.007 \mathrm{~kg} / \mathrm{s}$ in Case 4$)$. Thus, the char recycling scheme cannot help to increase the carbon conversion rate or improve the gasification performance if a high ash content coal is used. To reduce the char moving toward the wall by the centrifugal force generated by the tangential injection scheme in the first stage, an alternative injection scheme, such as opposing jets injection in the first stage could be considered.

\section{Conclusions}

In this study, the ash deposition has been modeled by assuming that all of the particles will be trapped on the 

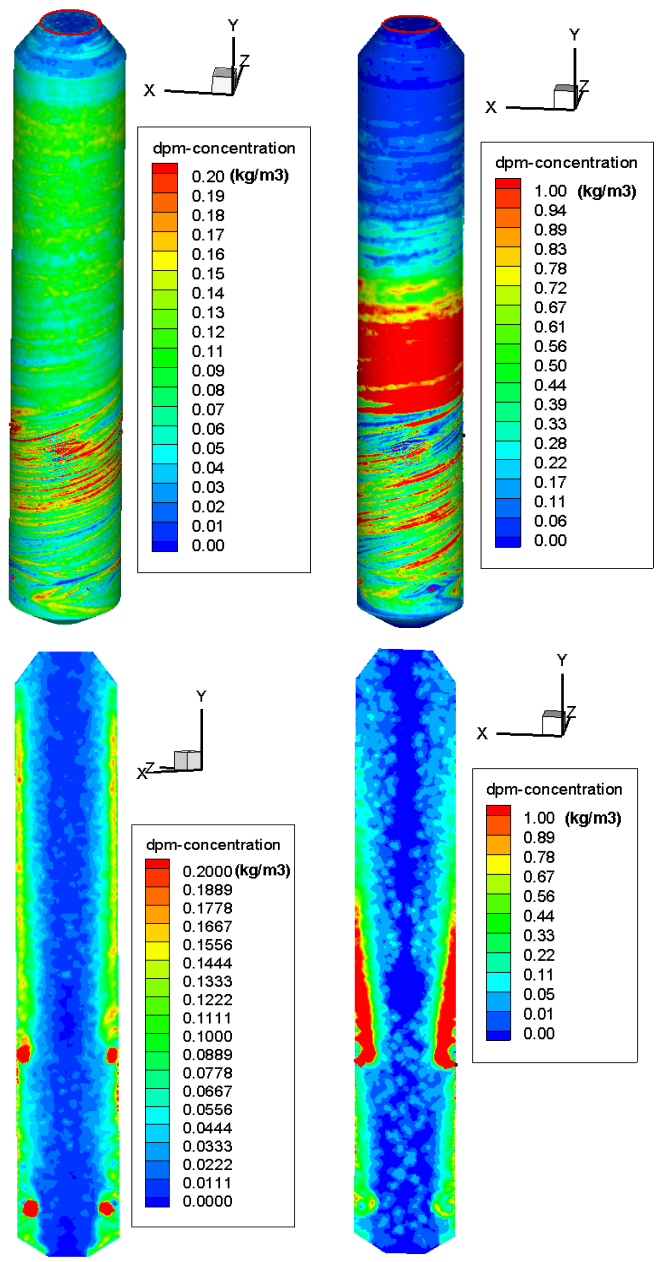

\section{IL-6 coal (Case 2) WK-11 coal (Case 4)}

Figure 5. Coal particle concentrations for Cases 2 and 4. (The upper figures show the coal particle concentration on the wall while the lower figures show the coal particle concentration on the central plane).

Table 5. The syngas composition, temperature and HHV at exit of gasifier for Cases 2 and 4.

\begin{tabular}{ccc}
\hline Syngas (vol\%) & Case 2 IL-6 & Case 4 WK-11 \\
\hline $\mathrm{CO}$ & 0.39 & 0.28 \\
$\mathrm{CO}_{2}$ & 0.11 & 0.10 \\
$\mathrm{H}_{2}$ & 0.32 & 0.34 \\
$\mathrm{H}_{2} \mathrm{O}$ & 0.10 & 0.19 \\
Other Species & 0.08 & 0.09 \\
Exit T (K) & 1902 & 1015 \\
HHV (kJ/kmol) & 206,303 & 184,142 \\
Total HHV Rate $(\mathrm{kJ} / \mathrm{s})$ & 188,706 & 114,432 \\
Carbon Conversion Rate & $98 \%$ & $52 \%$ \\
Char at Exit $(\mathrm{kg} / \mathrm{s})$ & 0.010 & 0.007 \\
Total Char Deposition on the Wall $(\mathrm{kg} / \mathrm{s})$ & 0.092 & 1.752 \\
Ash at the Exit $(\mathrm{kg} / \mathrm{s})$ & 0.097 & 0.016 \\
Total Ash Deposition on the Wall $(\mathrm{kg} / \mathrm{s})$ & 0.922 & 3.619 \\
\hline
\end{tabular}



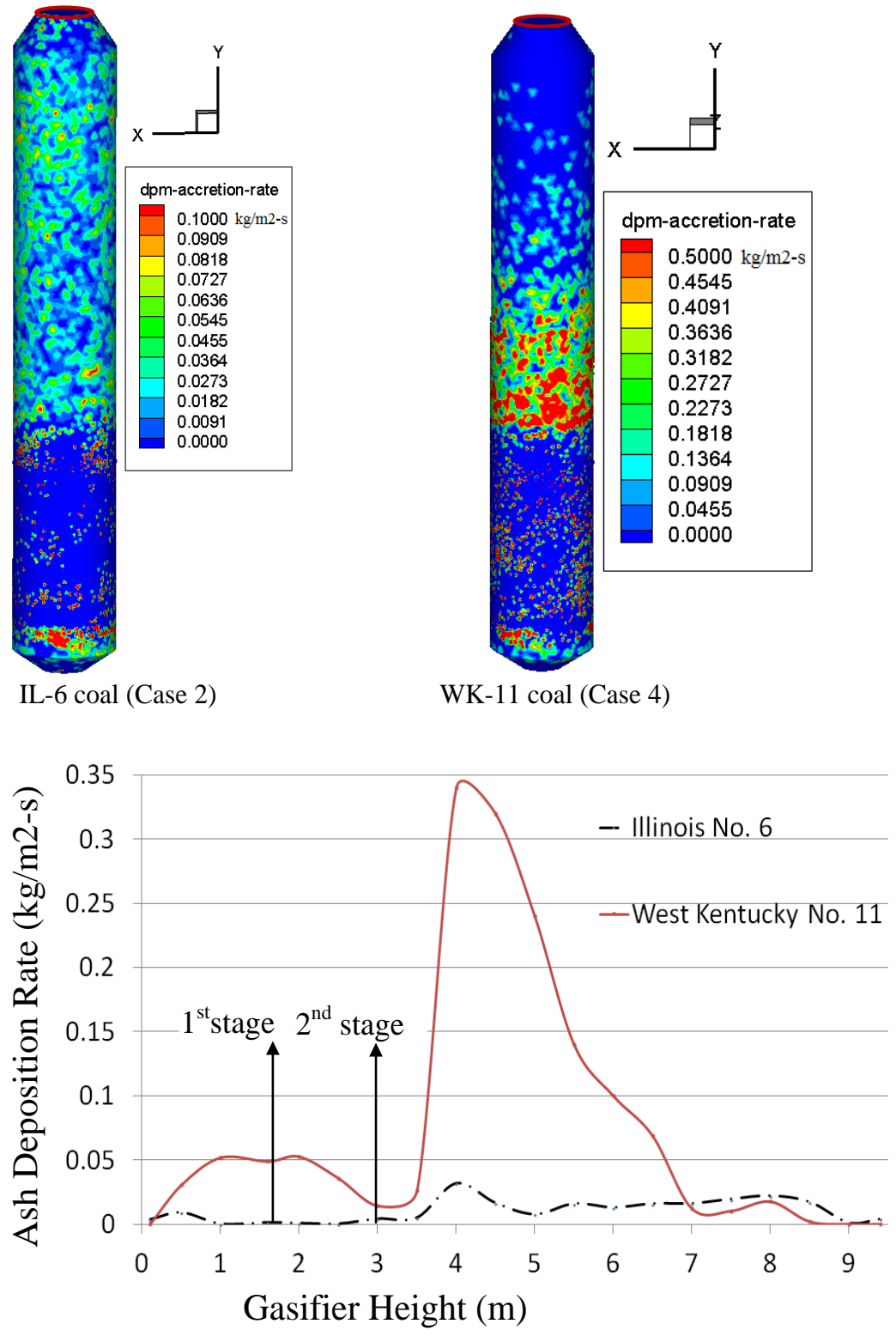

Figure 6. Contour of and area-weighted average ash deposition rates along the gasifier wall for Cases 2 and 4.

wall once they touch the wall and no further char reaction will occur at the wall. The ash deposition rate and deposition distribution are investigated by modeling the complete coal gasification process. Each coal particle has been tracked by the Lagrangian method as it goes through the process of coal surface moisture evaporation, devolatilization, coal combustion, coal gasification, and ash deposition. Both moisture and ash are treated as part of the coal particles in the discrete phase model. The ash deposition rates along the gasifier wall are investigated and compared between different cases by employing four different coal stage-feeding schemes. Both a low-ash coal (IL-6) and a high-ash coal (WK-11) are considered. The effect of the ash deposition rate on gasification performance, including syngas temperature, composition, and higher heating value (HHV), and the carbon conversion rate are also investigated in this study. A further modeling of the growth of the deposition layer and its interaction with the flow is left for future study. The conclusions are summarized below:

- Both the one-stage and the 50\% - 50\% two-stage fuel feeding cases show the peak ash deposition rate appears at the same location-at the height of $4 \mathrm{~m}$, but the peak ash deposition rate of the two-stage feeding case is $37 \%$ of the one-stage feeding case. When the fuel feeding increases at the second stage (the $25 \%$ - 
$75 \%$ case), the peak ash deposition rate rises to the height of $7.5 \mathrm{~m}$, and the value decreases to $53 \%$ of that from the one-stage fuel feeding case.

- A two-stage fuel feeding scheme could distribute the ash into a larger gasifier's wall surface area and, hence, reduce the peak ash deposition rate and make the ash distribution more uniform within the gasifier.

- Compared to the low-ash-content coal (Ill-6) gasification, the high-ash-content coal (WK-11) gasification has both a high peak ash deposition rate and a high overall ash deposition rate. The peak ash deposition rate of WK-11 is around $0.35 \mathrm{~kg} / \mathrm{m}^{2}$-s, which is about 11 times that of IL-6. The overall area-weighted average ash deposition rate on the gasifier wall of WK-11 coal is $0.12 \mathrm{~kg} / \mathrm{m}^{2}-\mathrm{s}$, which is 6.7 times that of IL-6 $(0.018$ $\left.\mathrm{kg} / \mathrm{m}^{2}-\mathrm{s}\right)$.

- The high-ash-content coal gasification has a low syngas HHV and carbon conversion rate. The total syngas HHV of WK-11 is $114,432 \mathrm{~kJ} / \mathrm{s}$, only $61 \%$ of the value $(188,706 \mathrm{~kJ} / \mathrm{s})$ of IL-6. The carbon conversion rate in WK-11 coal is $52 \%$.

- To reduce the char moving toward the wall by the centrifugal force generated by the tangential injection scheme in the first stage, an alternative injection scheme, such as opposing jets injection in the first stage could be considered.

The result of ash deposition rate in this study can be used as a boundary condition to provide ash particle influx distribution for use in slagging models.

\section{Acknowledgements}

This study was partially supported by the Louisiana Governor's Energy Initiative via the Clean Power and Energy Research Consortium (CPERC) administered by the Louisiana Board of Regents and partially supported by a US Department of Energy subcontract via Nicholls State University.

\section{References}

[1] Sahu, P. (2010) Characterization of Coal Combustion By-products (CCBs) for Their Effective Management and Utilization. Thesis, Department of Mining Engineering, National Institute of Technology, Rourkela, Orissa.

[2] Chen, L., Yong, S. and Ghoniem, A. (2012) Modeling the Slag Behavior in Three Dimensional CFD Simulation of a Vertically-Oriented Oxy-Coal Combustor. The 37th International Technical Conference on Clean Coal \& Fuel Systems, Clearwater, 3-7 June 2012.

[3] Beér, J. (2000) Combustion Technology Developments in Power Generation in Response to Environmental Challenges. Progress in Energy and Combustion Science, 26, 301-27. http://dx.doi.org/10.1016/S0360-1285(00)00007-1

[4] Feng, J., Shen, Y. and Yang, R. (2003) Principles and Calculations of Boilers. 3rd Edition, Science Press, Beijing.

[5] Shao, Y. (2011) Investigation of Ash Deposition during Co-Firing Biomass/Peat with Coal in a Pilot-scale FluidizedBed Reactor. Ph.D. Thesis, University of Western Ontario London, Ontario.

[6] Couch, G. (1994) Understanding Slagging and Fouling in pf Combustion. IEA Coal Research, London.

[7] Xu, L., Lee, J. and Kim, H. (2007) Comparison of Low Temperature Ash Deposition Determined by Theoretical and Experimental Method in Coal Gasifier Condition. World of Coal Ash (WOCA), 7-10 May 2007, Northern Kentucky.

[8] Barroso, J., Ballester, J., Ferrer, L. and Jiménez, S. (2006) Study of Coal Ash Deposition in an Entrained Flow Reactor: Influence of Coal Type, Blend Composition and Operating Conditions. Fuel Processing Technology, 87, 737-752. http://dx.doi.org/10.1016/j.fuproc.2006.02.004

[9] Fernandez-Turiel, J., Georgakopoulos, A., Gimeno, D., Papastergios, G. and Kolovos, N. (2004) Ash Deposition in a Pulverized Coal-Fired Power Plant after High-Calcium Lignite Combustion. Energy \& Fuels, 18, 1512-1518. http://dx.doi.org/10.1021/ef0400161

[10] Cao, Z., Sun, L., Cao, X. and He, Y. (2011) Study on Fly Ash Adhesion Characteristics and Deposition Mechanism in Shell Coal Gasification Process. Advanced Materials Research, 233-235, 789-793.

[11] Ahmadi, G., Mazaheri, A., Liu, C. and Gamwo, I. (2002) Computer Modeling of Flow, Thermal Condition and Ash Deposition in a Hot-Gas Filtration Device. Proceedings of the 5th International Symposium on Gas Cleaning at High Temperatures, Morgantown, 17-20 September 2002.

[12] Schulze, K., Scharler, R. and Obernberger, I. (2011) Development of an Advanced CFD Model for Ash Deposit and Aerosol Formation in Biomass Fired Boilers. Proceedings of the 9th European Conference on Industrial Furnaces and Boilers, Estoril, 26-29 April 2011.

[13] Yong, S., Gazzino, M. and Ghoniem, A. (2012) Modeling the Slag Layer in Solid Fuel Gasification and Combustion- 
Formulation and Sensitivity Analysis. Fuel, 92, 162-170. http://dx.doi.org/10.1016/j.fuel.2011.06.062

[14] Yong, S. and Ghoniem, A. (2012) Modeling the Slag Layer in Solid Fuel Gasification and Combustion-Two-Way Coupling with CFD. Fuel, 97, 457-466. http://dx.doi.org/10.1016/j.fuel.2012.02.063

[15] Lu, X. and Wang, T. (2013) Water-Gas Shift Modeling in Coal Gasification in an Entrained-Flow Gasifier, Part 1: Development of Methodology and Model Calibration. Fuel, 108, 629-638.

[16] Lu, X. and Wang, T. (2013) Water-Gas Shift Modeling in Coal Gasification in an Entrained-Flow Gasifier, Part 2: Gasification Application. Fuel, 108, 620-628.

[17] DOE/NETL Report (2011) Cost and Performance Baseline for Fossil Energy Plants Volume 3a: Low Rank Coal to Electricity: IGCC Cases. National Energy Technology Laboratory.

[18] Chen, C., Horio, M. and Kojima, T. (2000) Numerical Simulation of Entrained Flow Coal Gasifiers. Chemical Engineering Science, 55, 3861-3833. http://dx.doi.org/10.1016/S0009-2509(00)00030-0

[19] Westbrook, C.K. and Dryer, F.L. (1981) Simplified Reaction Mechanisms for the Oxidation of Hydrocarbon Fuels in Flames. Combustion Science and Technology, 27, 31-43. http://dx.doi.org/10.1080/00102208108946970

[20] Jones, W.P. and Lindstedt, R.P. (1988) Global Reaction Schemes for Hydrocarbon Combustion. Combustion and Flame, 73, 233-249. http://dx.doi.org/10.1016/0010-2180(88)90021-1

[21] Benyon, P. (2002) Computational Modelling of Entrained Flow Slagging Gasifiers. Ph.D. Thesis, School of Aerospace, Mechanical \& Mechatronic Engineering, University of Sydney, Sydney.

[22] Silaen, A. and Wang, T. (2010) Effect of Turbulence and Devolatilization Models on Gasification Simulation. International Journal of Heat and Mass Transfer, 53, 2074-2091. http://dx.doi.org/10.1016/j.ijheatmasstransfer.2009.12.047

[23] Lu, X. and Wang, T. (2014) Investigation of Low Rank Coal Gasification in a Two-Stage Downdraft Entrained-Flow Gasifier. International Journal of Clean Coal and Energy, 3, 1-12. http://dx.doi.org/10.4236/ijcce.2014.31001

[24] Lu, X. and Wang, T. (2013) Investigation of Radiation Models in Entrained-flow Coal Gasification Simulation. International Journal of Heat and Mass Transfer, 67, 377-392.

[25] Li, A., and Ahmadi, G. (1992) Dispersion and Deposition of Spherical Particles from Point Sources in a Turbulent Channel Flow. Aerosol Science and Technology, 16, 209-226. http://dx.doi.org/10.1080/02786829208959550

[26] Saffman, P. (1965) The Lift on a Small Sphere in a Slow Shear Flow. Journal of Fluid Mechanics, 22, 385-400. http://dx.doi.org/10.1017/S0022112065000824

[27] Kallio, G. and Reeks, M. (1989) A Numerical Simulation of Particle Deposition in Turbulent Boundary Layers. International Journal of Multiphase Flow, 15, 433-446.

[28] Talbot, L., Cheng, R., Schefer, R. and Willis, D. (1980) Thermophoresis of Particles in a Heated Boundary Layer. Journal of Fluid Mechanics, 101, 737-758. http://dx.doi.org/10.1017/S0022112080001905

[29] Energy Laboratory at Brigham Young University (2014) Ash Fusion Temperature. http://www.et.byu.edu/ larryb/Ash\%20Fusion\%20Temperatures_1.html 